\title{
PERANAN LUMBUNG PANGAN DALAM MENJAGA KETAHANAN PANGAN DI KABUPATEN TABANAN
}

\author{
The Role Of Foodstuffs In Keeping Food Security In Tabanan District
}

\section{A.A.A.Wulandira Sawitri Dj, I Made Sudarma}

\author{
Program Studi Agribisnis, Fakultas Pertanian, Universitas Udayana, Bali, Indonesia
}

Email:djelantikwulan@yahoo.co.id

\begin{abstract}
The aim of the research was to determine the role of food storage in maintaining food security, the factors that influence the existence of food storage in maintaining food security, and the constraints faced by rural communities in developing and strengthening food barns towards food security. The research location was in Tabanan Regency which was determined purposively. The population in this study were all members of the food barn or subak found in the locations of the Dwi Dharma and Subak Serongga Food Barn. The sampling technique used the proportional random sampling method. This study used descriptive qualitative analysis, namely analysis presented in the form of tables, words, schemes, or images / graphics. The results of the study showed that the role of food barns in maintaining food security was a place to store food for all its members, overcome food shortages if they experience crop failure or during the dry season and increase group income. A good understanding factor and the benefits received by farmers or barns for the existence of food barns were the drivers of the existence of sustainable food storage and this study also found that there were almost no significant obstacles in the development of barns.
\end{abstract}

Keywords: food storage, food security, income

\begin{abstract}
ABSTRAK
Penelitian ini bertujuan untuk mengetahui peranan lumbung pangan dalam menjaga ketahanan pangan, faktorfaktor yang mempengaruhi eksistensi lumbung pangan dalam menjaga ketahanan pangan, dan kendala-kendala yang dihadapi masyarakat pedesaan dalam mengembangkan dan memperkuat lumbung pangan menuju ketahanan pangan. Lokasi penelitian adalah di Kabupaten Tabanan yang ditentukan secara purposive. Populasi dalam penelitian ini adalah semua anggota lumbung pangan atau subak yang terdapat di lokasi Lumbung Pangan Dwi Dharma dan Subak Serongga. Teknik pengambilan sampel menggunakan metode proposional random sampling. Penelitian ini menggunakan analisis kualitatif deskriptif, yaitu analisis yangdisajikan dalam bentuk tabel, kata, skema, atau gambar/grafik. Hasil penelitian menunjukkan bahwa peranan lumbung pangan dalam menjaga ketahanan pangan adalah sebagai tempat untuk menyimpan pangan bagi semua anggotanya, mengatasi kekurangan pangan apabila mengalami gagal panen atau pada saat musim paceklik dan meningkatkan pendapatan kelompok. Faktor pemahaman yang baik dan adanya manfaat yang diterima petani atau anggota lumbung pangan atas keberadaan lumbung pangan menjadi pendorong keberadaan lumbung pangan secara berkelanjutan dan penelitian ini juga menemukan bahwa hampir tidak ada kendala yang berarti dalam pengembangan lumbung pangan.
\end{abstract}

Kata Kunci : lumbung pangan, ketahanan pangan,pendapatan

\section{Pendahuluan}

\section{Latar Belakang}

Ketahanan pangan nasional merupakan isu strategis bagi Indonesia mengingat kecukupan produksi, distribusi, dan konsumsi pangan memiliki dimensi luas dengan masalah sosial, ekonomi, dan politik.Ketahanan pangan merupakan sistem terintegrasi yang memiliki subsitem utama seperti ketersediaan pangan, keterjangkauan, dan pemenuhan konsumsi pangan. Ketersediaan pangan harus dikelola sedemikian rupa sehingga produksi pangan yang bersifat musimandan tersebar antar wilayah harus tersedia dalam jumlah yang cukup serta stabil untuk masyarakat dari waktu ke waktu.Selain untuk menjaga kesenjangan antara produksi dengan kebutuhan, cadangan pangan juga berfungsi untuk mengantisipasi terjadinya kekurangan pangan yang disebabkan gangguan atau terhentinya pasokan bahan pangan.

Pemenuhan ketahanan pangan pedesaan tidak bisa dilepaskan dari adanya kelembagaan lumbung pangan desa yang akan menampung hasil panen petani sebelum dijual kepasaran. Upaya ini diharapkan akan mampu memberikan kontribusi 
yang berarti terhadap perwujudan ketahanan pangan, sehingga lembaga sosial ekonomi masyarakat ini mampu menjadi lembaga penggerak ekonomi perdesaan. Pengembangan lumbung masyarakat dilaksanakan dalam tiga tahapan yaitu tahap penumbuhan, tahap pengembangan, dan tahap kemandirian. Tahap penumbuhan mencakup identifikasi lokasi dan pembangunan fisik lumbung melalui Dana Alokasi Khusus (DAK) bidang pertanian, tahap pengembangan mencakup identifikasi kelompok lumbung pangan dan pengisian cadangan pangan melalui dana belanja bantuan sosial, dan tahap kemandirian mencakup penguatan kelembagaan kelompok melalui pemberian dana belanja bantuan sosial agar mampu mengembangkan usaha untuk menunjang keberlanjutan kelembangan lumbung pangan.

Kabupaten Tabanan merupakan salah satu kabupaten di Provinsi Bali yang telah mendapat DAK bidang pertanian untuk mengembangkan lumbung pangan sejak tahun 2011.Dari sejak tahun 2011-2015 telah terdapat 11 subak yang mendapatkan DAK untuk lumbung pangan namun belum pernah dilakukan penelitian tentang peranan lumbung pangan dimaksud dalam menjaga ketahanan pangan di Kabupaten Tabanan. Berdasarkanuraikan diatas, makapenelitianinibertujuan untuk mengidentifikasi :

1. Peranan lumbung pangan dalam menjaga ketahanan pangan

2. Faktor-faktor yang mempengaruhi eksistensi lumbung pangan dalam menjaga ketahanan pangan.

3. Kendala-kendala yang dihadapi masyarakat pedesaan dalam mengembangkan dan memperkuat lumbung pangan menuju ketahanan pangan.

\section{METODE PENELITIAN}

\section{Lokasi Penelitian}

Penentuan lokasi penelitian dilakukan secara sengaja (purposive), yaitu di Kabupaten Tabanan dengan pertimbangan bahwa Kabupaten Tabanan merupakan lumbung pangan untuk Provinsi Bali.Sejak digulirkannya program ini secara nasional pada tahun 2009, telah terdapat sebelas subak yang mendapat fasilitasi DAK dalam bentuk bantuan sosial (bansos). Berdasarkan sebelas subak yang telah difasilitasi oleh pemerintah melalui DAK, lokasi penelitian ditetapkan di dua lokasi yang dipilih secara random dengan tahun penerimaan bansos sebagai strata, yaitu di Lumbung Pangan Dwi Dharma, Desa Tunjuk, Kecamatan Tabanan mewakili penerima bansos tahun 2013 dan Subak Serongga, Desa Pangkung Karung, Kecamatan Kerambitan mewakili penerima bansos lumbung pangan tahun 2014.

\section{Populasi dan Sampel}

Populasi dalam penelitian ini adalah semua anggota lumbung pangan atau subak yang terdapat di lokasi Lumbung Pangan Dwi Dharmadan Subak Serongga. Berdasarkan data yang dikumpulkan di lapangan jumlah anggota Lumbung Pangan Dwi Dharma adalah sebanyak 300 orang, sedangkan jumlah anggota Subak Serongga adalah sebanyak300 orang.

\section{Teknik Pengambilan Sampel}

\section{Metode penarikan sampel}

Metode penarikan sampel atau responden yang digunakan dalam penelitian ini adalah dengan menggunakan metode proposional random sampling yaitu sampel ditetapkan sebanyak $10 \%$ dari jumlah populasi.Berdasarkan metode tersebut diatas, maka jumlah sampel atau responden dalam penelitian ini adalah sebanyak 60 orang, yang terdiri dari 30 responden merupakan anggota Lumbung Pangan Dwi Dharma, dan 30 responden adalah anggota Subak Serongga.

\section{Pengambilan sampel}

Pengambilan Sampel di masing-masing strata subak dilakukan dengan proporsional random sampling yaitu pengambilan sampel secara acak dengan mempertimbangkan jumlah populasi di masingmasing subak strata.Pengambilan secara acak dilakukan dengan mengundi, menggunakan tabel bilangan acak atau dengan bantuan komputer.

\section{Metode Analisis Data}

Metode analisis yang digunakan untuk menjawab tujuan penelitian, yaitu mengetahui peran lumbung pangan dalam membangun ketahanan pangan,faktor-faktor yang mempengaruhi eksistensi lumbung pangan serta kendala-kendala yang dihadapi oleh lumbung pangan dipergunakan analisis kualitatif deskriptif, yaitu analisis yangdisajikan dalam bentuk tabel, kata, skema, atau gambar/grafik. Penelitian deskriptif kualitatif menafsirkan dan menuturkan data yang bersangkutan dengan situasi yang terjadi, sikap serta pandangan yang terjadi di dalam masyarakat.

\section{HASIL DAN PEMBAHASAN}

\section{Karakteristik Responden}

Berdasarkan hasil penelitian, rata-rata umur responden adalah 55,68 tahun dengan kisaran umur antara 30 sampai 71 tahun, dengan tingkat pendidikan formal responden paling tinggi adalah tamat SMA sebesar $43,33 \%$, dan yang paling

A.A.A. Wulandira, et al., Peranan.. 21 
rendah adalah tamat sarjana sebanyak 3,34 \%. Kategori luas lahan garapan menunjukkan bahwa lahan yang dimiliki petani adalah lahan sawah, tegalan, dan pekarangan, yang memiliki total luas lahan sebesar 14,45 Ha dengan rata-rata 0,24 Ha. Karakteristik berdasarkan tingkat pendapatan berdasarkan 60 responden memiliki rata-rata pendapatan pertahun sebesar $\mathrm{Rp} 23.085 .950$ dan rata-rata per bulan sebesar $\mathrm{Rp} 1.923 .829$.

\section{Peranan Lumbung Pangan dalam Menjaga Ketahanan Pangan}

Lumbung pangan Dwi Dharma di Subak Seronggo Desa Pangkungkarung dan lumbung pangan di Desa Tunjuk memiliki peranan yang penting dalam kehidupan masyarakat petani. Hasil penelitian yang dilakukan memperoleh tiga peranan yaitu lumbung pangan berfungsi sebagai tempat menyimpan pangan, mengatasi kekurangan pangan apabila petani mengalami gagal panen atau saat mengahadapi musim paceklik, dan keberadaan lumbung pangan dapat meningkatkan pendapatan kelompok bagi petani.

Keberadaan lumbung pangan di Subak Seronggo dan Desa Tunjuk memang sangat dirasakan manfaatnya. Lumbung pangan digunakan sebagai tempat untuk menyimpan hasil panen petani. Mekanisme penyimpanan di kedua lokasi lumbung pangan berbeda tergantung aturan yang dimiliki dan disepakati oleh semua anggota masing-masing lumbung pangan. Lumbung pangan di Subak Seronggo menetapkan aturan bahwa dalam setiap kali panen, petani diharuskan untuk menyerahkan sebagian hasil panennya untuk disimpan di lumbung pangan. Mekanisme penyerahan hasil panen adalah setiap $1 \mathrm{Ha}$ luas lahan menyerahkan $25 \mathrm{~kg}$ gabah atau padi untuk disimpan. Sedangan di Lumbung Pangan Dwi Dharma mempunyai mekanisme penyimpanan yang berbeda. Penyimpanan hasil panen hanya didapat dari pengembalian pinjaman . Setiap anggota lumbung pangan yang meminjam beras atau gabah diharuskan mengembalikan sebesar pinjaman ditambah dengan bunga sebesar $1 \%$ dari pinjaman pada saat panen. Bunga tersebut yang disimpan di lumbung pangan.

Modal awal lumbung pangan didapat dari bantuan sosial (bansos) dari pemerintah sebesar Rp 200.000.000 kemudian ditambah dengan simpanan dari anggota. Hasil panen petani yang disimpan dapat berupa gabah atau beras. Hal ini sesuai dengan tujuan didirikannya lumbung pangan untuk mencukupi ketersedian pangan anggotanya.

Selain sebagai tempat menyimpan hasil panen, lumbung pangan juga berperan untuk mengatasi kekurangan pangan pada saat petani mengalami gagal panen atau pada saat musim paceklik. Pada saat panen petani tidak selalu mendapatkan hasil panen yang bagus dan sesuai harapan. Ada kalanya faktor cuaca yang buruk meyebabkan panen yang sedikit dari seharusnya. Pada saat-saat seperti itulah petani dapat mengatasi dengan cara meminjam di lumbung pangan. Hal ini sangat membantu petani sehingga mereka tidak perlu terlalu mengkawatirkan ketersediaan pangan mereka. Hampir sebagian besar petani/anggota kedua lumbung pangan tersebut telah merasakan bantuan dengan adanya program yang diadakan oleh lumbung pangan tersebut.

Lumbung pangan juga berperan dalam meningkatkan pendapatan kelompok. Persediaan pangan di lumbung akan semakin bertambah dari waktu ke waktu seiring dengan semakin banyaknya petani yang memanfaatkan bantuan dari lumbung pangan tersebut. Hal itu juga memberikan dampak positif pada pendapatan kelompok lumbung pangan. Pada saat harga pangan sedang tinggi, sebagian persediaan pangan yang ada di lumbung akan dijual. hasil penjualan akan digunakan untuk pengelolaan lumbung pangan itu sendiri.

Faktor-Faktor Yang Mempengaruhi Eksistensi Lumbung Pangan

Hasil analisis menunjukkan bahwa keberadaan lumbung pangan sampai saat ini di Subak Seronggo dan lumbung pangan Dwi Dharma dipengaruhi oleh dua faktor. Faktor yang pertama adalah pemahaman yang baik anggota kelompok terhadap program lumbung pangan. Dari 60 responden, hampir seluruhnya mengetahui tentang pengertian dan tujuan didirikannya lumbung pangan. Sebagian besar responden mengetahui lumbung pangan adalah sebagai tempat untuk penyimpanan gabah dan beras, sehingga pada saat musim paceklik tidak mengalami kekurangan gabah dan beras, dan responden juga mengetahui tujuan program lumbung pangan diadakan sebagai cadangan gabah/beras bagi petani yang membutuhkan atau petani yang mengalami kekurangan pangan. Hal tersebut akan membuat keberadaan lumbung pangan akan terjaga.

Faktor kedua adalah pemahaman responden terhadap manfaat yang dapat diterima oleh anggota kelompok lumbung pangan. Dari 60 responden, semuanya mengetahui manfaat dari adanya program lumbung pangan tersebut. Bahkan sebelum program lumbung pangan ini disosialisasikan oleh pemerintah keberadaan lumbung pangan atau yang biasa disebut "jineng" sudah memberikan manfaat kepada petani. Sehingga pada saat pemerintah mengajukan program lumbung pangan secara lebih terkoordinasi, para petani menyambut dan menerima dengan sangat baik. Kedua hal inilah yang membuat keberadaan program lumbung

A.A.A. Wulandira, et al., Peranan.. 22 
pangan di Kabupaten Tabanan dapat berjalan dengan baik.

Melalui indepth interview yang dilakukan peneliti kepada pihak pengelola lumbung pangan serta pekaseh dan kepala desa diperoleh keinginan dari para anggota untuk lebih meningkatkan dan mengembangkan program lumbung pangan yang sudah berjalan seperti membentuk koperasi. Hal ini mebuktikan bahwa keberadaan lumbung pangan sangat memberikan manfaat bagi petani/anggota lumbung pangan itu sendiri.

Kendala-Kendala yang Dihadapi Petani dalam mengembangkan dan Memperkuat Lumbung Pangan menuju Ketahanan Pangan

Hasil penelitian juga menemukan bahwa tidak ada kendala yang berarti di dalam pengembangan lumbung pangan. Kalaupun terdapat masalah tidak dianggap berarti karena semuanya dapat dipecahkan secara kebersamaan di dalam lumbung pangan dan tidak mengganggu kegiatan lumbung pangan. Ini berarti bahwa keberadaan lumbung pangan di Subak seronggo dan di lumbung pangan Dwi Dharma khususnya dan di kabupaten Tabanan umumnya dapat diterima oleh masyarakat petani dan memberi manfaat dalam pemecahan masalah dalam ketersediaan pangan.

\section{SIMPULAN DAN SARAN}

\section{Simpulan}

Berdasarkan hasil analisis dan pembahasan yang telah dilakukan, maka dapat disimpulkan, (1) Peranan lumbung pangan dalam menjaga ketahanan pangan adalah menyimpan pangan bagi petani, mengatasi kekurangan pangan apabila petani mengalami gagal panen/musim paceklik dan meningkatkan pendapatan kelompok, (2) Faktorfaktor yang mempengaruhi keberadaan lumbung pangan dalam menjaga ketahanan pangan adalah faktor pemahaman terhadap lumbung pangan dan manfaat yang diterima petani, dan (3) Tidak ada kendala yang dihadapi dalam pengembangan lumbung pangan untuk menuju ketahanan pangan.

\section{Saran}

Berdasarkan hasil pembahasan dan kesimpulan yang diperoleh maka saran yang dapat disampaikan dalam penelitian ini, yaitu(1)Bantuan sosial (bansos) yang diberikan pemerintah agar lebih ditingkatkan dari kuantitasnya sehingga pengembangan lumbung pangan lebih cepat terwujud, dan (2)Dibutuhkan inovasi program dari pemerintah guna menunjang keberlanjutan lumbung pangan.

\section{UCAPAN TERIMAKASIH}

Ucapan terimakasih ini penulis tunjukan kepada seluruh pihak yang telah membantu dalam pelaksanaan penelitian hingga karya ilmiah ini dapat dipublikasikan di e-jurnal.

\section{DAFTAR PUSTAKA}

Irawan, B., Simatupang, P., Sugiarto, Supadi,Agustin N.K., Sinuraya, J.F. 2006. "Panel Petani Nasional (PATANAS): Analisis Indikator Pembangunan Pertanian dan Pedesaan". Laporan Akhir Penelitian. PSEKP-Badan Penelitian dan Pengembangan Pertanian. Departemen Pertanian, Jakarta.

Nurmanaf, A.R., Sugiarto, Julin, A., Supadi, Agustin, N.K., Sinuraya, J.F., dan Zakaria A.K. 2005. "Panel Petani Nasional (PATANAS), Dinamika Sosial Ekonomi Rumah Tangga dan Masyarakat Pedesaan: Analisis Profitabilitas Usahatani dan Dinamika Harga dan Upah Pertanian". Laporan Akhir Penelitian. PSEKP-Badan Penelitian dan Pengembangan Pertanian. Departemen, Pertanian, Jakarta.

Peraturan Menteri Pertanian Republik Indonesia Tahun 2014 Nomor 08 /Permmentan /OT.140/1/2014. Pedoman Pengembangan Lumbung Pangan Masyarakat Tahun 2014, Kementrian Pertanian, Jakarta

Rusastra I.W., Noekman K.M., Supriyati, Erma, S., Elizabeth, R., dan Suryadi, M. 2005. "Analisis Ekonomi Ketenagakerjaan Sektor Pertanian dan Pedesaan di Indonesia".PSEKP-Badan Penelitian dan Pengembangan Pertanian, Departemen Pertanian, Jakarta.

Saliem, H.P., Purwoto, A., Hardono, G.S., Purwantini, T.B., Supriyatna, Y., Marisa, Y. dan Waluyo. 2005. "Manajemen Ketahanan Pangan Era Otonomi Daerah dan Perum Bulog". PSEKP-Badan Penelitian dan Pengembangan Pertanian, Departemen Pertanian, Jakarta. 